\title{
CHARACTERIZATION OF TRACE METALS IN TSP ALONG A DENSE TRAFFIC HIGHWAY IN OGBOMOSO, NIGERIA
}

\author{
Adejoke O, Alamu \\ Department of Chemical Engineering, \\ Ladoke Akintola University of Technology, \\ Ogbomoso, Nigeria.
}

Sunday A., Adebanjo

Department of Chemical and Polymer Engineering Lagos State University, Epe Campus, Lagos, Nigeria

\begin{abstract}
Total Suspended Particles (TSP) in ambient air were collected at seven spots along a dense traffic highway in Ogbomoso, Nigeria. Particulate matters in TSP were extracted from filters by digestion method using a mixture of $\mathrm{HNO}_{3}$ and $\mathrm{H}_{2} \mathrm{O}_{2}$, and the extract was analyzed for ten trace metals using Atomic Absorption Spectrophotometer (AAS). The concentration of TSP in air varied from $69.44-185.19 \mu \mathrm{g} / \mathrm{m}^{3}$ while the average concentration of the trace metals in TSP were 43.91, 36.99, 30.79, 48.28, 31.84, 302.5, 46.79, 105, 39.36 and $336 \mu \mathrm{g} / \mathrm{m}^{3}$ for $\mathrm{Cd}, \mathrm{Cr}, \mathrm{Mn}, \mathrm{Pb}, \mathrm{Zn}, \mathrm{Cu}, \mathrm{AS}, \mathrm{Ca}, \mathrm{Ni}$ and $\mathrm{Fe}$, respectively. The mean concentrations of trace metals in TSP were found in the order of $\mathrm{Fe}>\mathrm{Cu}>\mathrm{Ca}$ $>\mathrm{Pb}>\mathrm{As}>\mathrm{Cd}>\mathrm{Ni}>\mathrm{Cr}>\mathrm{Zn}>\mathrm{Mn}$. Correlation studies showed that the trace metals originated from common source along the highway: Cd was highly correlated with $\mathrm{Cu}(\mathrm{r}=\mathbf{0 . 8 5 1 6}), \mathrm{Cr}$ was highly correlated with $\mathrm{Mn}(\mathrm{r}=\mathbf{0 . 7 8 4 4})$, Pb with $\mathrm{Mn}(\mathrm{r}=$ 0.7455), Ca with $\mathrm{Cr}(\mathrm{r}=\mathbf{0 . 7 5 8 1})$ and $\mathrm{Zinc}(\mathrm{r}=\mathbf{0 . 8 4 7 1})$, and $\mathrm{Ni}$ with $\mathrm{Cd}(\mathrm{r}=0.7325)$. Trace metals concentration in TSP along Ogbomoso Section of Ibadan-Ilorin highway were higher than WHO and FEPA standard limits of trace metals in air but much lower than the values reported in other cities of the world. Enrichment factor analysis showed that $\mathrm{Cd}, \mathrm{Cr}$ $\mathrm{Zn}, \mathrm{Cu}, \mathrm{As}, \mathrm{Pb}$ and $\mathrm{Ni}$ originated from anthropogenic sources, majorly traffic and industrial activities while $\mathrm{Fe}, \mathrm{Mn}$ and $\mathrm{Ca}$ were of crustal origin.

Keywords- TSP, Trace metals, Enrichment Factor, Highway.
\end{abstract}

\section{INTRODUCTION}

Atmospheric transport and deposition of aerosol is a significant source of trace metals to the earth surface. Total suspended particles (TSP) in ambient air are frequently considered as atmospheric pollutants due to

\author{
Lukuman A., Jimoda \\ Department of Chemical Engineering, \\ Ladoke Akintola University of Technology, \\ Ogbomoso, Nigeria. \\ Abass O. Alade \\ Department of Chemical Engineering, \\ Ladoke Akintola University of Technology, \\ Ogbomoso, Nigeria
}

their ability to bind to toxic substances and hazardous matter. Many studies have shown the close relationships between the high concentrations of TSP and an increased risk of respiratory symptoms, cancer and even mortality rates [1, 2]. Besides their adverse effects on visibility[3], TSP have been found to be the carriers of pathogenic bacteria that lead to fatal diseases[4] and toxic metals that result in human dysfunction and various diseases [5,1]. Metals in particulate matter (PM) usually have both natural and anthropogenic origins. Natural sources such as crustal minerals, forest fires and oceans; and anthropogenic sources such as industrial activities, waste incineration, fossil fuel burning[6,7,1], traffic emissions [8], were the principal contributors to metals in the ambient air [9].

Traffic emissions have been reported as the most significant local particle source affecting urban air quality in metropolitan area [10,11]. Non-crustal elements associated with particulate matter near the highways mostly come from vehicle emissions[12,13]. Studies conducted on vehicular emissions along highway in several urban regions such as New Jersey, (US), Helsinki Metropolitan area (Finland) and Dhaka, (Bangladesh) $[14,15,16$, have shown that the concentration of trace elements varied as a function of distance from highway[17]. There is a major concern about trace metals, such as $\mathrm{Ca}, \mathrm{As}, \mathrm{Cd}, \mathrm{Cu}, \mathrm{Fe}, \mathrm{Pb}, \mathrm{Zn}, \mathrm{Cr}, \mathrm{Ni}$, and $\mathrm{Mn}$, because of their toxicity and potential carcinogenic property, increased mortality rates and their persistence in the environment $[18,19,20,21,22]$.

Ogbomoso axis of Ibadan-Ilorin highway being a major route linking the Northern and Southern parts of Nigeria has witnessed an increased traffic level by cars and motor cycles due to the influx of both staff and students to the university and the university teaching hospital, which were not in existence some years ago, coupled with traffic 


\section{International Journal of Engineering Applied Sciences and Technology, 2020 \\ Vol. 5, Issue 6, ISSN No. 2455-2143, Pages 307-317 \\ Published Online October 2020 in IJEAST (http://www.ijeast.com)}

flow of heavy trucks along the highway. All these have given rise to high traffic emissions and dust generation. This paper presents the concentration level of total suspended particles (TSP) and the trace metal components $(\mathrm{Ca}, \mathrm{As}, \mathrm{Cd}, \mathrm{Cu}, \mathrm{Fe}, \mathrm{Pb}, \mathrm{Zn}, \mathrm{Cr}, \mathrm{Ni}$, and $\mathrm{Mn}$ ) in ambient air in Ogbomoso. The contributing source of the trace metals is investigated with the use of the enrichment factor analysis.

\section{MATERIALS AND METHODS}

\subsection{Sampling site and sampling procedures}

\subsubsection{Sampling site}

Ogbomoso city is a pre-colonial urban centre and the second largest city, both in terms of population and spatial extent, in Oyo State, Nigeria. The city is situated in South-Western Nigeria ( $4^{\circ} 16^{\prime} 0^{\prime \prime}$ East; $8^{\circ} 8^{\prime} 0^{\prime \prime}$ North) (Fig 1).It is located at a distance of about $100 \mathrm{~km}$ north of Ibadan, the Oyo State capital, and about $52 \mathrm{~km}$ from Ilorin, Kwara State capital. The map of the study area is shown in Fig. 2. It is one of the important gateways to the Northern part of Nigeria from the Yoruba land. It develops laterally towards the north and south along the IbadanIlorin road [23]. The city is characterized by two distinct seasons: dry (November - March) and wet (April October) with a mean annual rainfall of $1200 \mathrm{~mm}$ distributed seasonally. Temperature ranges are small and constant throughout the year. Its hottest month records $32.48{ }^{\circ} \mathrm{C}\left(90^{\circ} \mathrm{F}\right)$ and its coolest month $26.88^{\circ} \mathrm{C}\left(70{ }^{\circ} \mathrm{F}\right)$ with the temperature range of not more than $8{ }^{\circ} \mathrm{C}\left(20^{\circ} \mathrm{F}\right)$. Being located along Ibadan - Oyo - Ilorin route, Ogbomoso has witnessed growth in road traffic. There has not been an increase in industrial activities along the highway. Major industries in the town include small agricultural processing industries, welders workshop, paint and pharmaceutical industries. On the other hand, there has been an increase in the number of vehicles for personal and commercial use in the town. Thus, traffic emission and road dust are expected to be the major sources of air pollution along the highway. The selection of the sampling site was based on several factors including nearness to the highway, minimizing potential for sample contamination, and ease of access. Based on the above criteria, seven sampling spots were chosen along Ogbomoso section of Ibadan-Ilorin highway. The characteristics of the sampling spots are given in Table 1. This research work was carried out along Ibadan- Ilorin highway that spans Ogbomoso town-ship. TSP samples were collected on filters and the filters were analyzed for ten trace metals using AAS.

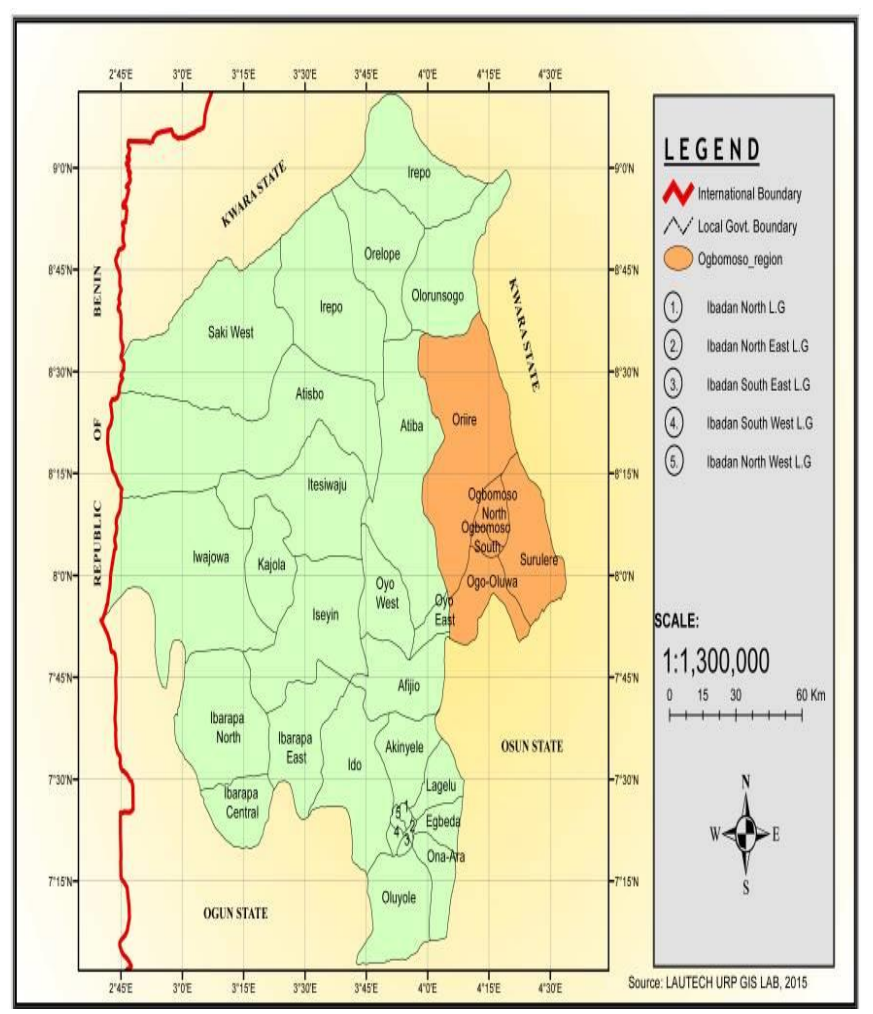

Fig. 1. Location of Ogbomoso in Oyo State.

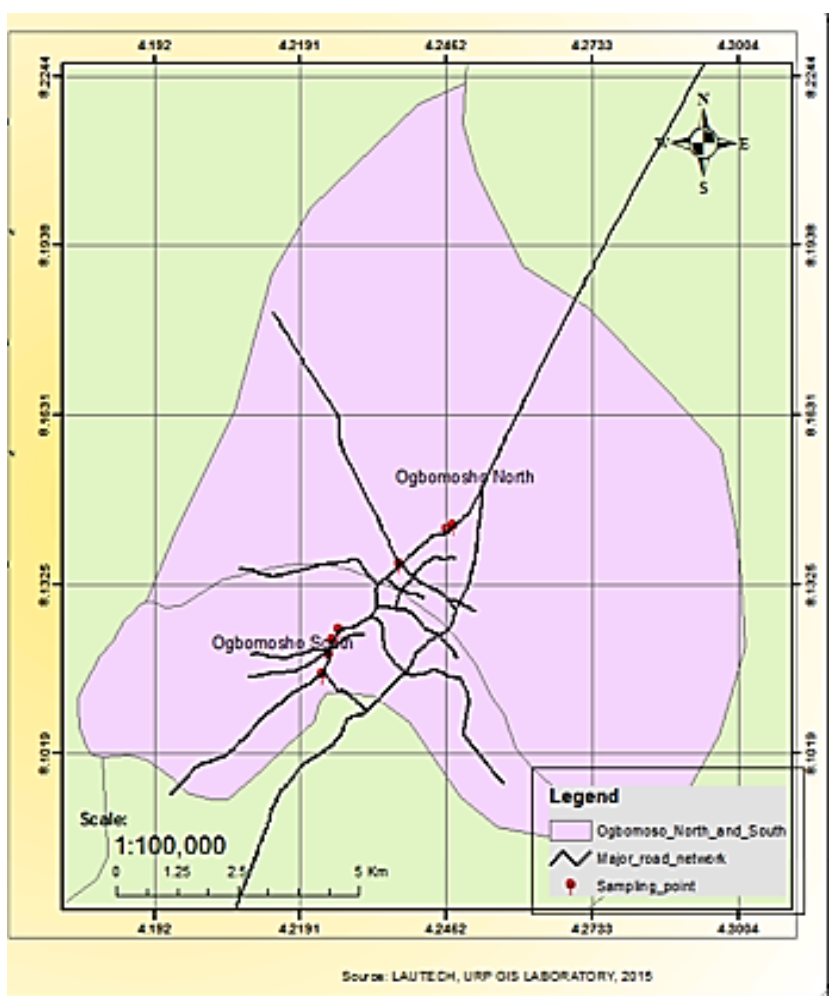

Fig. 2. Sampling Spots along Ogbomoso Section of Ibadan-Ilorin Highway. 


\section{International Journal of Engineering Applied Sciences and Technology, 2020 \\ Vol. 5, Issue 6, ISSN No. 2455-2143, Pages 307-317 \\ Published Online October 2020 in IJEAST (http://www.ijeast.com)}

Table -1 Characteristics of the Sampling Locations

\begin{tabular}{llll}
\hline Sampling location & $\begin{array}{l}\text { Height of sampling } \\
\text { location }(\mathrm{m})\end{array}$ & $\begin{array}{l}\text { Distance from the } \\
\text { highway }(\mathrm{m})\end{array}$ & Description \\
\hline $\begin{array}{l}\text { High school } \\
\text { Idi Oro }\end{array}$ & 3.5 & 12.5 & $\begin{array}{l}\text { Intersection with high traffic } \\
\text { Medium traffic, welder activities, } \\
\text { filling station }\end{array}$ \\
$\begin{array}{l}\text { California } \\
\text { Olopemarun }\end{array}$ & 4.8 & 16 & $\begin{array}{l}\text { Medium traffic, welder activities } \\
\text { Medium traffic, welder activities, } \\
\text { iron bender, animal feed } \\
\text { High traffic, filling station, motor } \\
\text { park, road construction, } \\
\text { commercial activities }\end{array}$ \\
Takie & 10.6 & 15.3 & $\begin{array}{l}\text { High traffic, filling stations, } \\
\text { motor park }\end{array}$ \\
Starlight & 7.4 & 4.2 & $\begin{array}{l}\text { High traffic, commercial } \\
\text { activities }\end{array}$ \\
Sabo & 4.67 & 16.9 & \\
\hline
\end{tabular}

\subsubsection{Sampling Procedure}

Total suspended particles were collected on filters by gravimetric air sampling method using Negretti air sampler (Model NR 700). A sampling period of 6 hours was adopted. In this method, air samples were drawn from the atmosphere using a vacuum pump with a flow rate of $12 \mathrm{lmin}^{-1}$ through pre-weighed cellulose filters (Whatman) of size $2.5 \mathrm{~cm}$ diameter. Prior to use, the filters including the blank filters were desiccated and tarred, then placed in an aluminum foil and a zip-lock bag. After sampling, the filters were desiccated (to remove any moisture content) and re-weighed using a high-precision balance (Mettler Toledo XP6) to determine the change in the weight of the filters. The weight of TSP on the filters were determined by subtracting the initial weight from the final weight [24]. The loaded filters were then placed in an aluminium foil and sealed in a plastic zip-lock bag until analysis to minimize contamination and kept in freezer until chemical analysis to limit losses of volatile components [16]. Filter blanks were stored and processed in an identical manner as the loaded filters.

\subsection{TSP Mass Concentrations}

Mass concentrations of TSP was calculated using equation 1

Concentration of TSP $=\frac{10^{6}(W 2-W 1)}{Q \times t}$

Where,

$W_{1}=$ weight of the filter before sampling $(\mathrm{g}), W_{2}=$ weight of the filter after sampling,
$Q=$ volumetric flow rate of inlet air $\left(\mathrm{m}^{3} /\right.$ hour $), 10^{6}=$ conversion from $\mathrm{g}$ to $\mu \mathrm{g}$

$\mathrm{t}=$ time in hour

\subsection{Concentration of Trace Metals in TSP}

The concentrations of the selected trace metals: $\mathrm{Ca}, \mathrm{As}, \mathrm{Cd}, \mathrm{Cu}, \mathrm{Fe}, \mathrm{Pb}, \mathrm{Zn}, \mathrm{Cr}, \mathrm{Ni}$ and $\mathrm{Mn}$ in $\mathrm{TSP}$, were determined as follows: the filters were separately digested in a $20 \mathrm{ml}$ mixture of nitric acid $\left(\mathrm{HNO}_{3}\right)$ and perchloric acid $\left(\mathrm{HClO}_{3}\right)$ in ratio 2:1 [25], and then diluted to $25 \mathrm{ml}$ with distilled-deionized water. The digest $(25 \mathrm{ml})$ was used to determine the concentrations of the selected trace metals ( $\mathrm{Ca}, \mathrm{As}, \mathrm{Cd}, \mathrm{Cu}, \mathrm{Fe}, \mathrm{Pb}, \mathrm{Zn}, \mathrm{Cr}, \mathrm{Ni}$ and $\mathrm{Mn}$ ) using Buck Scientific Atomic Absorption Spectrometer (AAS Buck Scientific VGP 210 Model) at the Centre for Energy Research and Development (CERD) at Obafemi Awolowo University, Ile Ife, Nigeria. The instrument was calibrated with appropriate standards to obtain calibration curves. The background contamination was monitored using blanks filters (unexposed filters) that were treated in a similar manner with field samples.

\subsection{Enrichment Factor of Trace Metals in TSP}

The concentrations of trace metals in TSP should be linked to natural sources in the absence of anthropogenic sources. However, emissions from the various anthropogenic sources have drastically increased the concentrations of trace metals in our environment. To identify the origin of trace metals in precipitation, enrichment factors (EF) analysis is always applied, to show the degree of enrichment of a given element compared to the relative abundance of that element in crustal material. [26]. $\mathrm{Na}, \mathrm{K}, \mathrm{Al}, \mathrm{Mg}, \mathrm{Ca}, \mathrm{Mn}$ and $\mathrm{Fe}$ are used as the reference metals in most cases. Concentration 


\section{International Journal of Engineering Applied Sciences and Technology, 2020 \\ Vol. 5, Issue 6, ISSN No. 2455-2143, Pages 307-317 \\ Published Online October 2020 in IJEAST (http://www.ijeast.com)}

of trace metals detected in TSP samples were correlated and $\mathrm{Fe}$ showed the best correlation with all other metals hence, selected as the reference element [27,28]. Efs $<10$ indicate metals having crustal origin; $10<$ Efs $<100$ indicate moderate anthropogenic enrichment, showing greater concentrations of a particular metal in the TSP than would be expected from the crustal origin and metals with Efs $>100$ are considered to be of anthropogenic origin.

The enrichment factor was calculated using Equation (2)

$$
E F(X)=\frac{(X / F e)_{T S P}}{(X / F e)_{C r u s t}}
$$

Where: $E F(X)=$ enrichment factor, $(X / F e)_{T S P}=$ mean concentrations of the target element and Fe in TSP, and $(\mathrm{X} / \mathrm{Fe})_{\text {crust }}=$ mean concentrations of the target element and $\mathrm{Fe}$ in continental crust respectively. Efs $<10$ indicate metals having crustal origin; $10<$ Efs $<100$ indicate moderate anthropogenic enrichment, indicating greater concentrations of a particular metal in the TSP than would be expected from the crustal material and metals with Efs $>100$ are considered to be of anthropogenic origin.

\section{RESULTS AND DISCUSSION}

\subsection{TSP Mass Concentration}

The mass concentration of TSP determined at the seven sampling locations along the highway ranged from $69.444 \mu \mathrm{g} / \mathrm{m}^{3}$ to $185.185 \mu \mathrm{g} / \mathrm{m}^{3}$ as shown in Table 1 . The lowest concentration of TSP was observed at Olopemarun, while the highest was observed at Takie, suggesting a strong influence from local sources like vehicle emissions at the location. The average concentration of TSP along the highway, $116.07 \mathrm{\mu gm}^{-3}$, is much below the $250{\mu \mathrm{gm}^{-3}}^{-3}$ maximum daily TSP concentration set by the national environmental pollution regulatory body, Federal Environmental Protection Agency of Nigeria [29]. The average concentration of TSP $\left(116.07 \mu \mathrm{gm}^{-3}\right)$ obtained in this study is comparable with the result $\left(138.88 \mu \mathrm{gm}^{-3}\right)$ obtained around a transportation area in Lagos [30], and

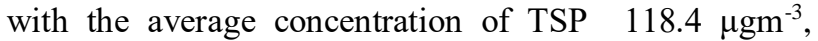
obtained Central Taiwan (Fang et al, 2014) but lower than the average concentration of TSP $\left(269.93 \mu \mathrm{gm}^{-3}\right)$ obtained at Calabar [31].
Table -1 TSP Mass Concentration

\begin{tabular}{lc}
\hline \multicolumn{1}{c}{ Sampling locations } & $\begin{array}{c}\text { Concentration of TSP } \\
\left(\mu \mathrm{gm}^{-3}\right)\end{array}$ \\
\hline High school & 115.70 \\
Idi oro & 138.89 \\
California & 92.59 \\
Olopemarun & 69.44 \\
Takie & 185.19 \\
Starlight & 115.74 \\
Sabo & 94.91
\end{tabular}

\subsection{Concentrations of Trace Metals in TSP}

The concentrations of the trace metals components of TSP in ambient air ranged from $22.94-$ $77.99 \mu \mathrm{g} / \mathrm{m} 3 ; 31.84-59.43 \mu \mathrm{g} / \mathrm{m}^{3} ; 22.45-40.41 \mu \mathrm{g} / \mathrm{m}^{3}$; $42.25-67.59 \mu \mathrm{g} / \mathrm{m}^{3} ; 29.18-47.76 \mu \mathrm{g} / \mathrm{m}^{3} ; 285.1-362.9$ $\mu \mathrm{g} / \mathrm{m}^{3} ; 39.80-67.35 \mu \mathrm{g} / \mathrm{m}^{3} ; 97.96-125.7 \mu \mathrm{g} / \mathrm{m}^{3} ; 38.33-$ $62.29 \mu \mathrm{g} / \mathrm{m}^{3}$ and $235.4-445.7 \mu \mathrm{g} / \mathrm{m}^{3}$ for $\mathrm{Cd}, \mathrm{Cr}, \mathrm{Mn}, \mathrm{Pb}$, $\mathrm{Zn}, \mathrm{Cu}, \mathrm{AS}, \mathrm{Ca}, \mathrm{Ni}$ and $\mathrm{Fe}$, respectively (Table 2). Among the trace elements in TSP samples, major contribution was noted for $\mathrm{Fe}$ and $\mathrm{Cu}$. Increasing trend of average trace metals concentrations in the TSP revealed the following order: $\mathrm{Mn}<\mathrm{Zn}<\mathrm{Cr}<\mathrm{Ni}<\mathrm{Cd}<\mathrm{As}<\mathrm{Pb}<\mathrm{Ca}<\mathrm{Cu}<\mathrm{Fe}$. These values are higher than the daily standard limit set by WHO and ATSDR [32,33].

The results of trace metals component of TSP clearly showed that vehicles as pollution emission sources contribute differently to different trace elements in the ambient air, and there are regional differences with respect to the strength of pollutant emissions. Almost all elements showed their maximum concentrations at Takie suggesting stronger influence from anthropogenic sources, such as the increased vehicular traffic at this site except for $\mathrm{Zn}, \mathrm{Cr}$ and $\mathrm{Ca}$, which have the highest concentration at Olopemarun.

Table-2 Concentration of Trace Metals in TSP

\begin{tabular}{lcccccccccc}
\hline $\begin{array}{c}\text { Sampling } \\
\text { spots }\end{array}$ & \multicolumn{10}{c}{ Trace metals } \\
\cline { 2 - 10 } & $\mathrm{Cd}$ & $\mathrm{Cr}$ & $\mathrm{Mn}$ & $\mathrm{Pb}$ & $\mathrm{Zn}$ & $\mathrm{Cu}$ & $\mathrm{As}$ & $\mathrm{Ca}$ & $\mathrm{Ni}$ & $\mathrm{Fe}$ \\
\hline High school & 22.94 & 44.57 & 22.45 & 42.25 & 29.18 & 313.6 & 67.35 & 107.8 & 43.13 & 235.4 \\
Idi oro & 36.70 & 31.84 & 24.69 & 42.25 & 37.14 & 323.9 & 64.29 & 114.3 & 45.52 & 306.3 \\
\hline
\end{tabular}


International Journal of Engineering Applied Sciences and Technology, 2020

Vol. 5, Issue 6, ISSN No. 2455-2143, Pages 307-317

Published Online October 2020 in IJEAST (http://www.ijeast.com)

\begin{tabular}{lcccccccccc}
\hline California & 22.94 & 48.82 & 31.43 & 59.14 & 42.45 & 285.1 & 55.10 & 115.9 & 45.52 & 310.9 \\
Olopemarun & 64.23 & 59.43 & 38.16 & 50.69 & 47.76 & 326.6 & 61.22 & 125.7 & 47.92 & 445.7 \\
Takie & 77.99 & 55.18 & 40.41 & 67.59 & 39.80 & 362.9 & 64.29 & 122.5 & 62.29 & 418.3 \\
Starlight & 41.29 & 38.20 & 29.18 & 59.14 & 29.18 & 311.0 & 48.98 & 97.96 & 38.33 & 359.4 \\
Sabo & 45.88 & 36.08 & 29.18 & 50.69 & 34.49 & 331.8 & 39.80 & 99.59 & 43.13 & 272 \\
Average & 43.91 & 36.99 & 30.79 & 48.28 & 31.84 & 302.5 & 46.79 & 105 & 39.36 & 336 \\
\hline
\end{tabular}

The presence of $\mathrm{Cd}$ in the environment could be from natural sources but the other possible sources of $\mathrm{Cd}$ in this study may be through anthropogenic activities. It was concluded that the presence of industries and several combustion processes like the car emissions contributed to the atmospheric $\mathrm{Cd}$ in the study area [34]. Wear of the brake lining and of other metallic parts of vehicles have been reported to be the major source of $\mathrm{Cd}$ in the environment[35]. In a study [36], it was also discovered that the most concentration levels of $\mathrm{Cd}$ were recorded in traffic zone. $\mathrm{Cd}$ in the environment is traced to Di-methyl cadmium used in the production of tetraethyl lead and its emission could be linked to vehicle emissions[37]. The highest $(77.99 \mu \mathrm{g} / \mathrm{m} 3)$ and lowest $(22.94 \mu \mathrm{g} / \mathrm{m} 3)$ concentrations of $\mathrm{Cd}$ were detected at Takie and California, respectively. These concentrations are above the WHO, EPA and ATSDR standard value of $0.005-0.5$ $\mu \mathrm{g} / \mathrm{m} 3$ [32,33,38] (Table 3). The highest and lowest concentrations of $\mathrm{Cr}$ were observed at Olopemarun (59.43 $\left.\mu \mathrm{g} / \mathrm{m}^{3}\right)$ and Idi oro $\left(31.84 \mu \mathrm{g} / \mathrm{m}^{3}\right)$. These concentrations in
TSP are above EPA standard value of $0.006 \mu \mathrm{g} / \mathrm{m}^{3}$ [38] (Table 3). [39] attributed the high concentrations of $\mathrm{Cr}$ in bulk depositions to the elevated concentrations of these metals in the atmosphere.

The average concentration of $\mathrm{Pb}\left(48.28 \mu \mathrm{g} / \mathrm{m}^{3}\right)$ in TSP is higher than EPA standard value of $1.50 \mu \mathrm{g} / \mathrm{m}^{3}$ by EPA [38] and $0.50 \mu \mathrm{g} / \mathrm{m}^{3}$ by ATSDR [33] (Table 3). Lead is one of the major trace elements in urban environment due to its long residence time in the environment. The presence of $\mathrm{Pb}$ in the environment could be due to several emission sources such as carbon black plant, non-ferrous metal smelting, steel and pipe manufacturing plants, gas flare burning and heavy traffic of vehicles. However, the presence of $\mathrm{Pb}$ in TSP along Ogbomoso section of IbadanIlorin highway could be attributed to heavy traffic of vehicles since most of these industrial activities are rare along the highway. A high concentration of $\mathrm{Pb}$ in zones with higher anthropogenic activities such as heavy traffic of vehicles [40].

Table-3 Comparison of Concentration of Trace Metals in TSP with Regulatory Standards ${ }^{\mathrm{a}} \mathrm{WHO}, 2000 ;{ }^{\mathrm{b}} \mathrm{EPA}, 2013 ;{ }^{\mathrm{c}} \mathrm{ATSDR}, 2002$

\begin{tabular}{|c|c|c|c|c|c|c|c|c|c|c|}
\hline \multirow[t]{2}{*}{ Body } & \multicolumn{8}{|c|}{ Trace Metals $\left(\mu \mathrm{g} / \mathrm{m}^{3}\right)$} & \multirow[b]{2}{*}{$\mathrm{Ni}$} & \multirow[b]{2}{*}{$\mathrm{Fe}$} \\
\hline & $\mathrm{Cd}$ & $\mathrm{Cr}$ & $\mathrm{Mn}$ & $\mathrm{Pb}$ & $\mathrm{Zn}$ & $\mathrm{Cu}$ & As & $\mathrm{Ca}$ & & \\
\hline $\mathrm{WHO}^{\mathrm{a}}$ & $\begin{array}{c}0.005- \\
0.5\end{array}$ & NA & 0.150 & NA & NA & NA & 0.007 & NA & 0.02 & NA \\
\hline $\mathrm{EPA}^{\mathrm{b}}$ & 0.006 & 0.006 & NA & 1.500 & 0.103 & 0.290 & NA & NA & NA & NA \\
\hline $\mathrm{ATSDR}^{\mathrm{c}}$ & 0.005 & NA & NA & 0.500 & NA & NA & NA & NA & NA & NA \\
\hline This study & 43.91 & 36.99 & 30.79 & 48.28 & 31.84 & 302.5 & 46.79 & 105 & 39.4 & 336 \\
\hline
\end{tabular}

Reports of some studies carried out in urban areas have shown that, a high concentration of $\mathrm{Pb}$ in the atmosphere was due to the effect of industrial and trafffic activities. It was also reported that a high concentration of $\mathrm{Pb}$ was always associated with high traffic density in Ogun state $[34,36]$.

Along Ogbomoso section of Ibadan-Ilorin highway, the primary source of $\mathrm{Zn}$ observed may be 


\section{International Journal of Engineering Applied Sciences and Technology, 2020 \\ Vol. 5, Issue 6, ISSN No. 2455-2143, Pages 307-317 \\ Published Online October 2020 in IJEAST (http://www.ijeast.com)}

probably from motor vehicle tyre wear caused by poor road surfaces, and the lubricating oils in which $\mathrm{Zn}$ is found as part of many additives such as zinc Dithiophosphates. This is because there are no major industrial activities, such as smelting operations, along the study area. [36] reported that the highest levels of $\mathrm{Zn}$ in wet deposition were shown in traffic and industrial stations. The highest and lowest concentrations of $\mathrm{Zn}$ were observed at Olopemarun $\left(47.76 \mu \mathrm{g} / \mathrm{m}^{3}\right)$ and High School and Starlight $\left(29.18 \mu \mathrm{g} / \mathrm{m}^{3}\right)$. [39] attributed the high concentrations of $\mathrm{Zn}$ in bulk depositions to the elevated concentrations of this metal in the atmosphere. [14] have reported tyre wear as one of the primary sources of $\mathrm{Zn}$ in the urban atmosphere. The fact that $\mathrm{Zn}$ primarily originates from the wear of vehicle tyre and other components can be further supported by the findings from the studies undertaken by $[41,42]$. The average concentration of $\mathrm{Zn}\left(31.84 \mu \mathrm{g} / \mathrm{m}^{3}\right)$ in TSP is higher than EPA standard value of $0.103 \mu \mathrm{g} / \mathrm{m}^{3}$ [38] (Table 3).

The average concentration of $\mathrm{Cu}\left(302.5 \mu \mathrm{g} / \mathrm{m}^{3}\right)$ in TSP is higher than EPA standard value of $0.290 \mu \mathrm{g} / \mathrm{m}^{3}$ [38] (Table 3). High Copper concentration in TSP along the highway could be due to vehicular emissions along the highway. In a study[43], the presence of $\mathrm{Cu}$ was attributed to vehicular emissions or oil combustion and re-suspended road dust. Wang et al [44] also attributed the presence of copper to chemical industries and intensive traffics. Most of man-made emissions of As originate from metal smelters which is emitted in form of arsenites or arsenates whereas natural sources are from volcanic activities. These activities are rare in the study areas and this explains the low concentration of As in the environment.

Ni pollution along the highway could be due to smoking of cigarette because WHO asserted that mainstream cigarette smoke contains 0.040.58 micrograms $\mathrm{Ni} /$ cigarette and consuming 20 cigarette/day will increase the ambient $\mathrm{Ni}$ value by 15 times [32]. The highest and lowest concentrations of $\mathrm{Ni}$ were observed at Olopemarun $\left(62.29 \mu \mathrm{g} / \mathrm{m}^{3}\right)$ and High School and Starlight $\left(38.33 \mu \mathrm{g} / \mathrm{m}^{3}\right)$. The average concentration of $\mathrm{Ni}\left(39.36 \mu \mathrm{g} / \mathrm{m}^{3}\right)$ in TSP was above the WHO standard value of $0.020 \mu \mathrm{g} / \mathrm{m}^{3}$ [32] (Table 3).

For $\mathrm{Fe}$, the highest $\left(445.7 \mu \mathrm{g} / \mathrm{m}^{3}\right)$ and lowest $\left(235.4 \mu \mathrm{g} / \mathrm{m}^{3}\right)$ concentrations were detected at Olopemarun and High School, respectively. The presence of Fe in TSP along the highway could be due to the natural origin of the studied area and tear of certain parts of vehicles moving on the road. It can also be from dropping of metal scraps by the roadsides. A very high concentration of $\mathrm{Fe}$ to the occurrence of $\mathrm{Fe}$ at high concentrations in Nigerian soils. The presence of $\mathrm{Fe}$ was also reported in emissions from heavy-duty vehicles $[45,46]$.

\subsection{Pearson's Correlation Matrix among the Trace Metals Measured in Wet Deposition}

Correlation coefficient is a measure of the linear correlation between two variables and giving a value between +1 and -1 . Where 1 is total positive correlation, 0 is no correlation, and -1 is the total negative correlation. It is usually performed to distinguish the possible common sources of constituents $[47,16]$.

The Pearson's correlation matrix among the trace metals measured in TSP along Ogbomoso section of Ibadan-Ilorin Highway are presented in Table 4. All positive and strong correlations indicate relationship among the trace metals in the same trend such that increase in the concentration of any suggests increase in concentration of the other. Concentration of $\mathrm{Cd}$ was moderately correlated with $\mathrm{Cr}(\mathrm{r}=0.5303)$ and $\mathrm{Pb}(\mathrm{r}=$ $0.5303)$ and highly correlated with $\mathrm{Mn}(\mathrm{r}=0.8476), \mathrm{Cu}(\mathrm{r}$ $=0.8516)$, As $(\mathrm{r}=0.9529)$ and $\mathrm{Ni}(\mathrm{r}=0.8653)$. Cr was highly correlated with $\mathrm{Zn}(\mathrm{r}=0.912), \mathrm{Cu}(\mathrm{r}=0.824)$ and $\mathrm{Ni}(\mathrm{r}=0.81)$ and moderately correlated with $\mathrm{Ca}(\mathrm{r}=0.71)$. $\mathrm{Mn}$ was strongly correlated with As (0.8662) and moderately correlated with $\mathrm{Fe}(\mathrm{r}=0.741)$. This strong correlation among metals shows that they originate from common source along the highway; traffic source.

Table -4 Pearson's correlation matrix among the trace metals measured in TSP

\begin{tabular}{|c|c|c|c|c|c|c|c|c|c|c|}
\hline & $\mathrm{Cd}$ & $\mathrm{Cr}$ & $\mathrm{Mn}$ & $\mathrm{Pb}$ & $\mathrm{Zn}$ & $\mathrm{Cu}$ & As & $\mathrm{Ca}$ & $\mathrm{Ni}$ & $\mathrm{Fe}$ \\
\hline $\mathrm{Cd}$ & 1 & & & & & & & & & \\
\hline $\mathrm{Cr}$ & 0.5303 & 1 & & & & & & & & \\
\hline Mn & 0.8476 & 0.7844 & 1 & & & & & & & \\
\hline $\mathrm{Pb}$ & 0.5228 & 0.4581 & 0.7455 & 1 & & & & & & \\
\hline $\mathrm{Zn}$ & 0.4485 & 0.6709 & 0.7055 & 0.2321 & 1 & & & & & \\
\hline
\end{tabular}




\begin{tabular}{llllllllllll}
\hline $\mathrm{Cu}$ & 0.8516 & 0.2112 & 0.4975 & 0.2538 & 0.0922 & 1 & & & & \\
$\mathrm{As}$ & 0.0739 & 0.3866 & 0.0250 & -0.204 & 0.1985 & 0.1665 & 1 & & & & \\
$\mathrm{Ca}$ & 0.4853 & 0.7581 & 0.6353 & 0.1796 & 0.8471 & 0.2761 & 0.6659 & 1 & & & \\
$\mathrm{Ni}$ & 0.7325 & 0.5993 & 0.7192 & 0.5291 & 0.4911 & 0.7203 & 0.4526 & 0.7197 & 1 & & \\
$\mathrm{Fe}$ & 0.7766 & 0.6017 & 0.8331 & 0.6029 & 0.5345 & 0.3816 & 0.0987 & 0.5066 & 0.4375 & 1
\end{tabular}

\subsection{Enrichment Factor Analysis}

The result obtained for enrichment factors (EFs) is presented in Table $4 . \mathrm{Cd}, \mathrm{Pb}, \mathrm{Cu}$ and As were significantly enriched with EFs of 24438.6, 156.319, 745.017, and 3252.412 respectively (Table 5). High EFs (> 100) were obtained for $\mathrm{Cd}, \mathrm{Pb}, \mathrm{Cu}$ and $\mathrm{As}$, indicating their anthropogenic origins. Among these elements, $\mathrm{Cu}$ is an additive in high-temperature lubricant and is present in brake linings, approximately $1-10 \%$ by weight [48], and it has been used successfully as a good tracer for wear emission of road traffic [49]. $\mathrm{Zn}$ is associated with wear tire debris because $\mathrm{Zn}$ is added to tires during vulcanization and is responsible for $1-2 \%$ of the tires by weight [50,51], and emissions from both vehicle exhaust and wear abrasion are important sources of $\mathrm{Pb}$. Correlation analyses (Table 4) illustrated that $\mathrm{Cd}, \mathrm{Pb}, \mathrm{Zn}$, $\mathrm{Cu}$ and As are well correlated with $(\mathrm{r}>0.75)$, suggesting that, similar to $\mathrm{Cu}$, these metals along Ogbomoso section of Ibadan-Ilorin highway originated mainly from wearabrasive sources. This indicates that they are contributed primarily by traffic and industrial emissions, rather than a natural origin. This is in concert with previous results $[52,53,54]$

Table -5 Enrichment Factor of Trace Metals in TSP

\begin{tabular}{cccc}
\hline Trace metals & $\begin{array}{c}\text { Mean concentration in TSP } \\
\left(\mu \mathrm{g} / \mathrm{m}^{3}\right)\end{array}$ & $\begin{array}{c}\text { Mean concentration in } \\
\text { crust }\left(\mu \mathrm{g} / \mathrm{m}^{3}\right)\end{array}$ & $\begin{array}{c}\text { Enrichment } \\
\text { factor }\end{array}$ \\
\hline $\mathrm{Cd}$ & 43.911 & 688.16 & 24438.6 \\
$\mathrm{Cr}$ & 36.991 & 212244.89 & 66.749 \\
$\mathrm{Mn}$ & 30.787 & 2132653.06 & 5.529 \\
$\mathrm{~Pb}$ & 48.28 & 118289.714 & 156.319 \\
$\mathrm{Zn}$ & 31.837 & 185714.286 & 65.657 \\
$\mathrm{Cu}$ & 302.505 & 155510.204 & 745.017 \\
$\mathrm{As}$ & 46.793 & 5510.204 & 3252.412 \\
$\mathrm{Ca}$ & 104.96 & 67755102.04 & 0.593 \\
$\mathrm{Ni}$ & 39.362 & 201257.143 & 74.906 \\
$\mathrm{Fe}$ & 335.999 & 128685714.3 & 1 \\
\hline
\end{tabular}

$\mathrm{Cr}, \mathrm{Zn}$ and $\mathrm{Ni}$ were moderately enriched by anthropogenic activities with EFs of 42.745 and 5.408 respectively. EFs (> 10) was obtained for $\mathrm{Cr}$, which was well correlated with $\mathrm{Cu}(\mathrm{r}>0.75)$, this suggests its anthropogenic origin. $\mathrm{Mn}$ and $\mathrm{Ca}$ were not enriched by anthropogenic sources due to very low EFs of 1.239 and 0.743 respectively, Enrichment factor of $\mathrm{Ca}$ was close to unity, which suggest that a dust source could account for at least half of the aerosol $\mathrm{Ca}$ budget. The $\mathrm{EF}$ values obtained for $\mathrm{Ca}$ was consistent with the results observed at Hsuehshan Tunnel in Taiwan [55]. The authors found out that $\mathrm{Ca}$ originated mainly from the resuspension of soil and road dust

The values showed that in the most cases, the heavy metals in TSP had anthropogenic origins. This result is similar to the results obtained by Farahmandkia et al [53], where the heavy metals in precipitation had anthropogenic 


\section{International Journal of Engineering Applied Sciences and Technology, 2020 \\ Vol. 5, Issue 6, ISSN No. 2455-2143, Pages 307-317 \\ Published Online October 2020 in IJEAST (http://www.ijeast.com)}

origins. Elements of anthropogenic origins $(\mathrm{Cd}, \mathrm{Pb}, \mathrm{Zn}$, $\mathrm{Cu}$ and $\mathrm{As}$ ) were highly enriched with respect to crustal composition indicating the influence of anthropogenic input for these metals. Iron $(\mathrm{Fe})$, which is considered an important crustal element, correlated well with Mn ( $\mathrm{r}=$ 0.8331 , Table 3.), demonstrating that crustal source is the major source of Fe. This is different from the results obtained at Hsuehshan Tunnel in Taiwan where wear dust was the major anthropogenic source of $\mathrm{Fe}$ in Hsuehshan Tunnel [55].

\section{CONCLUSION}

Concentrations of trace metals in TSP have been measured along a heavily trafficked highway in Ogbomoso, Nigeria. The peak values in the concentrations of the heavy metals were typically observed at Takie with the highest traffic density, regardless of the sample type. The Pearson's correlation matrix among the trace metals measured in TSP along the highway ranged from 0.987- 0.8471. All positive and strong correlations indicate relationship among the trace metals in the same trend such that increase in the concentration of any suggests increase in concentration of the other. Enrichment factor ranged from $0.593-24438.6 \mathrm{Cd}, \mathrm{Pb}, \mathrm{Zn}, \mathrm{Cu}$ and As were highly enriched with respect to crustal composition indicating the influence of anthropogenic input for these metals. The concentration of TSP at the seven sampling spots along the highway ranged from $69.444 \mu \mathrm{g} / \mathrm{m}^{3}$ to $185.185 \mu \mathrm{g} / \mathrm{m}^{3}$. It was also found that the highest concentration of TSP at all the sampling locations were below the daily limit of 150 $\mu \mathrm{g} / \mathrm{m} 3$ except at Takie where it was beyond the limit.

Several of our observations also support the need for extended observations and analysis of these heavy metals in the urban environment.

\section{Acknowledgment}

The authors would like to thanks the Center for Energy Research and Development (CERD), Obafemi Awolowo University, Ile Ife, for carrying out the analysis.

\section{REFERENCES}

[1] Duan, J. C. and Tan, J. H. (2013). Atmospheric Heavy Metals and Arsenic in China: Situation, Sources and Control Policies. Atmospheric Environment, vol. 74 (pp.93-101).

[2] Contini, D.; Cesari, D.; Donateo, A.; Chirizzi, D.; Belosi, F. (2014). Characterization of $\mathrm{PM}_{10}$ and $\mathrm{PM}_{2.5}$ and their Metals Content in Different Typologies of Sites in South-Eastern Italy. Atmosphere, vol. 5, (pp. 435-453).
[3] Tao, J.; Ho, K. F.; Chen, L. G.; Zhu, L. H.; Han, J. L.; Xu, Z.C.( 2009). Effect of Chemical Composition of $\mathrm{PM}_{2.5}$ on Visibility in Guangzhou, China. Particuology, vol. 7, (pp. 68-75).

[4] Gralton, J.; Tovey, E.R.; McLaws, M.L.; Rawlinson, W.D. (2013). Respiratory Virus RNA is Detectable in Airborne and Droplet Particles. Journal of Medical Virology, vol. 85, (pp. 21512159).

[5] Bollati, V.; Marinelli, B.; Apostoli, P.; Bonzini, M.; Nordio, F.; Hoxha, M.; Pegoraro, V.; Motta, V.; Tarantini, L.; Cantone, L.; et al.(2010) Exposure to Metal-rich Particulate Matter Modifies the Expression of Candidate MicroRNAs in Peripheral Blood Leukocytes. Environmental Health Perspectives, vol. 118, (pp. 763-768).

[6] Tian, H.Z.; Wang, Y.; Xue, Z.G.; Cheng, K.; Qu, Y.P.; Chai, F.H.(2010). Trend and Characteristics of Atmospheric Emissions of $\mathrm{Hg}$, As, and Se from Coal Combustion in China, 1980-2007. Atmospheric Chemistry and Physics, vol. 10 (pp.11905-11919).

[7] Zheng, N.; Liu, J.S.; Wang, Q.C.; Liang, Z.Z. (2010). Health Risk Assessment of Heavy Metal Exposure to Street Dust in the Zinc Smelting District, Northeast of China. Science Total Environment, vol. 408, (pp. 726-733).

[8] Kothai, P.; Saradhi, I.V.; Prathibha, P.; Hopke, P.K.; Pandit, G.G.; Puranik, V.D. (2008). Source Apportionment of Coarse and Fine Particulate Matter at Navi Mumbai, India. Aerosol Air Quality Research, vol. 8, (pp.423-436).

[9] Chang, S. H., Wang, K. S., Chang, H. F., Ni, W. W., Wu, B. J., Wong, R. H. and Lee, H. S. (2009). Comparison of Source Identification of Metals in Road-dust and Soil. Soil Sediment Contamination, vol. 18,: (pp. 669-683).

[10] Pirjola, L., Lähde, T., Niemi, J.V., Kousa, A., Rönkkö, T., Karjalainen, P., Keskinen, J., Frey, A. and Hillamo, R. (2012). Spatial and Temporal Characterization of Traffic Emissions in Urban Microenvironments with a Mobile Laboratory. Atmospheric Environment, vol. 63, (pp. 156-167).

[11] Soares, J., Kousa, A., Kukkonen, J., Matilainen, L., Kangas, L., Kauhaniemi, M., Riikonen, K., Jalkanen, J.N.P., Rasila, T., Hänninen, O., Koskentalo, T., Aarnio, M., Hendriks, C. and Karppinen, A. (2014). Refinement of a Model for Evaluating the Population Exposure in an Urban Area. Geoscience Model Development vol.7, (pp. 1885-1872).

[12] Ana Paula, G., Fontenele, Adalgiza F. and Jairo J. P. (2010). Measurements of Heavy Metals in Dry and 


\section{International Journal of Engineering Applied Sciences and Technology, 2020 Vol. 5, Issue 6, ISSN No. 2455-2143, Pages 307-317 \\ Published Online October 2020 in IJEAST (http://www.ijeast.com)}

Wet Deposition in São Paulo City. Article · January DOI: $\quad$ 10.1007/978-90-481-3043-6_12 https://www.researchgate.net/publication/2511207 $\underline{34}$

[13] Davis, B.S. and Birch. G.F. (2011). Spatial Distribution of Bulk Atmospheric Deposition of Heavy Metals in Metropolitan Sydney, Australia. Water, Air and Soil Pollution, vol. 214, (pp. 147-162).

[14] Xia, L. and Gao, Y. (2011). Characterization of Trace Elements in $\mathrm{PM}_{2.5}$ Aerosols in the Vicinity of Highways in Northeast New Jersey in the U.S. East Coast. Atmospheric Pollution Research, vol. 2, (pp. 34-44).

[15] Aurela, M., Saarikoski, S., Niemi, J. V., Canonaco, F., Prevot, A. S. H., Frey, A., Carbone, S., Kousa, A. and Hillamo, R. (2014). Chemical and Source Characterization of Submicron Particles at Residential and Traffic Sites in the Helsinki Metropolitan Area, Finland. Aerosol and Air Quality Research, vol. 10, (pp. 1-14).

[16] Islam, Md. F., Majumder, S. S., Al Mamun, A., Khan, Md. B., Rahman, M. A. and Salam, A. (2015). Trace Metals Concentrations at the Atmosphere Particulate Matters in the Southeast Asian Mega City (Dhaka, Bangladesh). Open Journal of Air Pollution, vol. 4, (pp. 86-98)

[17] Massoli, P., Fortner, E. C., Canagaratna, M. R., Williams, L. R., Zhang, Q., Sun, Y., Schwab, J. J., Onasch, T. B., Demerjian, K. L., Worsnop, D. R., Kolb, C. E. and Jayne, J. T. (2012). Pollution Gradients and Chemical Characterization of Particulate Matter from Vehicular Traffic near Major Roadways: Results from the 2009 Queens College Air Quality study in NYC, Aerosol Science and Technology, submitted, 2012.

[18] WHO, (2003). Health aspects of air pollution with particulate matter, ozone and nitrogen dioxide. World Health Organization. Copenhagen. 94.

[19] EEA, (2005). Environment and Health. European Environment Agency. Copenhagen, EEA Report No. 10/ 2005. 35.

[20] Taghinia Hejabi, A., Basavarajappa, H.T. and Qaid Saeed, A. M. (2010). Heavy Metal Pollution in Kabini River Sediments. International Journal of Environmental Research, vol. 4 No. 4, (pp. 629636).

[21] Sekhavatjou, M. S., Hoseini Alhashemi, A. and Rostami, A. (2011). Comparison of Trace Element
Concentrations in Ambient Air of Industrial and Residential Areas in Tehran City. Biological Trace Elements Research, vol. 8, No. 2, (pp. 335-346).

[22] Hosseini Alhashemi, A., Sekhavatjou, M. S., Hassanzadeh Kiabi, B. and Karbassi, A.R. (2012). Bioaccumulation of Trace Elements in Water, Sediment, and Six Fish Species from a Freshwater Wetland, Iran. Microchemical Journal, vol. 104, (pp. 1-6).

[23] Adeboyejo, A. T., Abolade, O. and Oshinowo, T. (2009). The Prevalence of Environment Related Diseases in Peri-Urban Areas of Ogbomoso. Ethiopian Journal of Environmental Studies and Management, vol. 2, No. 2, (pp. 73-83).

[24] Budhavant K. B., Rao P. S. and Safai, P. D. (2014). Chemical Composition of Snow-Water and Scavenging Ratios over Costal Antarctica. Aerosol and Air Quality Research, vol. 14, (pp. 666-676).

[25] Anf, H.Z., and Emad, S. (2014). An Environmental Impact Assessment of Open Burning of Scrap Tyres. Journal of Applied Science, vol. 14, No. 21, (pp. 2695-2703).

[26] Cocker, D.R. and Na, K. (2009). Characterization and Source Identification of Trace Elements in PM2.5 from Mira Loma, Southern California. Atmospheric Research, vol. 93, (pp. 793-800).

[27] Nazir, R., Shaheen, N. and Shah, M. H., (2011). Indoor/Outdoor Relationship of Trace Metals in the Atmospheric Particulate Matter of an Industrial Area. Atmospheric Research, vol. 101, (pp. 765772).

[28] Dubey, B., Pal, A. K. and Singh, G. (2012). Trace metal composition of airborne particulate matter in the coal mining and non-mining areas of Dhanbad Region, Jharkhand, India. Atmospheric Pollution Research, vol. 3, (pp. 238-246).

[29] FEPA (1991). Guidelines and Standards for Environment Pollution Control in Nigeria. Federal environmental protection agency, Federal Republic of Nigeria.

[30] Essiett, A.A. and Bede, M. C. (2015). Assessment of Total Suspended Particulates (TSP) in Ikot Abasi L. G. A., Nigeria. International Journal of Physics, vol. 3, No. 6, (pp. 230-232). 


\section{International Journal of Engineering Applied Sciences and Technology, 2020 Vol. 5, Issue 6, ISSN No. 2455-2143, Pages 307-317 \\ Published Online October 2020 in IJEAST (http://www.ijeast.com)}

[31] Ikamaise, V.C., Akpan, I.O., Essiett, A.A., Uwah, I.E. (2013). Concentrations and Source Apportionment of Total Suspended Particulate Matter in Calabar Air Basin. International Journal of Development and Sustainability, vol. 2, No. 2, (pp. 12031213).

[32] WHO, (2000). Guidelines for air quality. World HealthOrganization, Geneva. Retrieved from http://www.who.int/environmentalinformation/Air /Guidelines/aqguide7.pdf

[33] ATSDR, (2002). Regulations and guidelines applicable. Agency for Toxic Substances and Desease Registry. Reterived from http://www.atsdr.cdc.gov/toxprofiles/tp 11-c8.pdf

[34] Fatoba, P. O., Ogunkunle, C. O. and Olawepo, G. K. (2012). Assessment of Atmospheric Metal Depositions in the Industrial Areas of the Southwest of Nigeria. Ethiopian Journal of Environmental Studies and Management, vol. 5, No. 3, (pp. 260 -267).

[35] Arditsoglou, A. and Samara, C. (2005). Levels of Total Suspended Particulate Matter and Major Trace Elements in Kosovo: A Source Identification and Apportionment Study. Chemosphere, vol. 59, (pp. 669-678).

[36] Moaref, S., Sekhavatjou, M. S. and Hosseini Alhashemi, A. (2014). Determination of Trace Elements Concentration in wet and dry Atmospheric Deposition and Surface soil in the Largest Industrial city, Southwest of Iran. International Journal of Environmental Reseach, vol. 8, No. 2, (pp. 335-346).

[37] Scerbo, R., Ristori, T., Possenti, L., Lampugnami, L., Barale, R. and Barghigiani, C. (2001) Lichen (Xanthoria parientina) biomonitoring of trace element contamination and air quality assessment in Pisa Province, Italy. Science -Total Environment. Vol. 286, (pp. 27-40).

[38] EPA (2013). National Ambient Air Quality Standards for Particulate Matter; Final Rule, 2013. Federal Register.

[39] Gunawardena, J., Egodawatta, P., Ayoko, G.A. and Goonetilleke, A. (2012). Role of Traffic in Atmospheric Accumulation of Heavy Metals and Polycyclic Aromatic Hydrocarbons. Atmospheric Environment, Vol. 54, (pp. 502-510).

[40] Meena, M., Meena B. S., Chandrawat, U. and Rani, A., (2014). Characterization of Wet and Dry Deposition at an Industrial City of Western India.
International Journal of Innovative Research in Science, Engineering and Technology, vol.3, No.2, (pp. 9050-9056).

[41] Bai, J; Cui, B; Wang, Q; Gao, H; Ding, Q. (2009). Assessment of heavy metal contamination of roadside soils in Southwest China. Stochastic Environmental Research and Risk Assessment, vol. 23, (pp. 341-347).

[42] Adedeji, O. H., Olayinka, O. O., Oyebanji, and Oyebanji, F. F. (2013). Assessment of Traffic Related Heavy Metals Pollution of Roadside Soils in Emerging Urban Centres in Ijebu-North Area of Ogun State, Nigeria. Journal of Applied Science and Environmental Management: vol.17, No.4, (pp. 509-514).

[43] Farmaki, E.G. and Thomaidis, N.S. (2008), Current Status of the Metal Pollution of the Environment of Greece- a review.- Global Nest, vol.10, No. 3, (pp. 366-375).

[44] Wang, L. K., Chen, J. P, Hung, Y. and Shammas, N.K. (2009). Heavy Metals in the Environment. CRC Press, Taylor \& Francis Group, Boca Raton, FL. ISBN-13: 978-1-4200-7316-4.

[45] Adefemi, O.S; Olaofe, D. and Asaolu, S. S. (2007). Seasonal Variation in Heavy Metal Distribution in the Sediment of Major Dams in Ekiti-State. Pakistan Journal of Nutrition, 6 (6): 705-707

[46] Vallius, M (2005). Characteristics and sources of fine particulate matter in urban air. Publications of the National Public Health Institute, Department of Environmental Health Kuopio, Finland. Pp. 79-85.

[47] Wetang'ula, G. N. and Wamalwa, H. M. (2015). Trace Elements in Rainfall Collected around Menengai Area Kenya: Proceedings World Geothermal Congress, 201 Melbourne, Australia. Geothermal Development Co. Limited, P.O. Box 100746-00100, Nairobi Kenya gwetangula@gdc.co.ke, hwamalwa@gdc.co.ke

[48] Sanders, P. G., Xu, N., Dalka, T. M., and Maricq, M. M. (2003). Airborne Brake Wear Debris: Size Distributions, Composition, and a Comparison of Dynamometer and Vehicle Tests. Environmental Science and Technology, Vol. 37, (pp.4060-4069).

[49] Pio, C., Mirante, F., Oliveira, C., Matos, M., Caseiro, A., Oliveira, C., Querol, X., Alves, C., Martins, N., Cerqueira, M., Camões, F., Silva, H., and Plana, F. (2013). Size-segregated Chemical Composition of Aerosol Emissions in an Urban Road Tunnel in 
Portugal. Atmospheric Environment, vol. 71, (pp. $15-25)$.

[50] Degaffe, F. S. and Turner, A. (2011). Leaching of Zinc from Tire Wear Particles under Simulated Estuarine Conditions, Chemosphere, vol. 85, (pp. 738-743).

[51] Taheri, S., Khoshgoftarmanesh, A. H., Shariatmadari, H., and Chaney, R. L. (2011). Kinetics of Zinc Release from Ground Tire Rubber and Rubber Ash in a Calcareous Soil as Alternatives to $\mathrm{Zn}$ Fertilizers. Plant Soil, vol. 341, (pp. 89-91)

[52] Tanner, P. A., Hoi-Ling, M., and Yu, P. K. N. (2008). Fingerprinting Metals in Urban Street Dust in Beijing, Shanghai and Hong Kong. Environmental Science and Technology, vol. 42, (pp. 7111-7117).

[53] Farahmandkia, Z., Mehrasbi, M. R. and Sekhavatjou, M. S. (2011) Relationship between Concentrations of Heavy Metals in Wet Precipitation and Atmospheric PM10 Particles in Zanjan, Iran. Iran Journal of Environment, Health, Science and Engineering, vol.8, No(1), (pp. 49-56).

[54] Harrison, R. M., Jones A. M., Gielt, J., Yin, J., and Green, D. C. (2012). Estimation of the Contributions of Brake Dust, Tire Wear, and Resuspension to Non-exhaust Traffic Particles Derived from Atmospheric Measurements. Environmental Science and Technology, vol.46, (pp. 6523-6529).

[55] Li, Y. C., Tsai, C. J., Wu, Y. C., Zhang, R., K., Chi, K. H., Huang, Y. T., Lin, S. H. and Hsu, S. C. (2015). Characteristics of Trace Metals in Trafficderived Particles in Hsuehshan Tunnel, Taiwan: Size distribution, Potential Source, and Fingerprinting Metal Ratio. Atmospheric Chemistry and Physics, vol.15, (pp. 4117-4130) 